\title{
CHEMICAL COMPOSITION AND ORIGIN OF THE SHOCK METAMORPHIC ROCKS OF THE SÄÄKSJÄRVI AREA, FINLAND
}

\author{
Heikmi Papunen
}

\begin{abstract}
Papunen, Heikki 1973: Chemical composition and origin of the shock metamorphic rocks of the Sääksjärvi area, Finland. Bull. Geol. Soc. Finland 45, $29-34$.

Chemical compositions of the shock metamorphic rocks of the Lake Sääksjärvi area show that the breccias are considerably richer in potassium and silica and poorer in calcium than the country rocks around Lake Sääksjärvi. The textures suggest the impact metamorphic origin for the rocks but the differences in chemical composition indicate of endogenous explosive volcanism.
\end{abstract}

Heikki Papunen, Institute of geology and mineralogy, University of Turku, 20500 Turku 50, Finland.

\section{Introduction}

In a preceeding paper the author (Papunen 1969) described peculiar erratics found in the area southeast of Lake Sääksjärvi, Southwestern Finland. The rock types are not outcropped anywhere, but on the basis of the particular drift of the glaciogenic deposits and the geographical distribution of the blocks they evidently originate from the basin of Lake Sääksjärvi. As hand specimens and especially under a microscope most of the rock types differ drastically from the Precambrian rocks of the area. There is a congruency, however, between the blocks of Sääksjärvi and the »Kärnaites» (Saksela 1949) and other breccias of the Lappajärvi area, which is situated about $200 \mathrm{~km}$ NNE of Sääksjärvi. Owing to the planar features of quartz, Svensson (1968) proposed that Lappajärvi is an astrobleme. This presumption was confirmed by Lehtinen (1970) when he found coesite in the rocks of Lappajärvi. Under a microscope the rocks in question from Sääksjärvi show many textural features, which have been considered characteristic of shock metamorphic rocks. Of these, the most conspicuous are the intense brecciation and diversity of the breccia fragments, the vacuolization and oxidation of the rocks as well as planar features with low-index lamellae in quartz, reduction of birefricence, mosaic textures, planar features and transformation into maskelynite on feldspars.

Several mineralogical determinations were performed during the course of the studies. However, the variations are very complex and must be investigated more thoroughly before a detailed description is given.

This paper presents the results of the chemical analyses of the rock types. The problem of the origin of the rock types is discussed on the basis of the observed chemical composition. 


\section{Rock types}

In the preliminary paper the rock types were classified into four categories (Papunen 1969). The same classification applies in this study, but the rock types need some further comments and these are presented in the following paragraphs:

1) The first rock group is characterized by a porphyritic appearance. The rocks are dark gray in hand specimens and contain rare angular fragments of light granitic rocks. The texture is porphyritic with plagioclase as phenocrysts in the fine-grained plagioclase-augite-hornblende groundmass. In some samples there are numerous chlorite- and biotite-filled amygdules. On the whole, the rock type is fairly homogenous when compared to the following second, third and fourth rock groups, and the descriptive name "andesite» fits it well.

2) The vesicular unhomogenous breccias belong to the second group. The rocks are either greenish or brownish but the difference between the two subgroups is mainly based on the greater abundance of chlorite in the former and the oxidation of fragments and iron minerals in the latter. The numerous vesicles are either open, or partly or totally filled by zeolites, chlorite and silica. The groundmass is finegrained, very heterogenous and composed mainly of quartz and sanidine needles. The fragments are angular or rounded and the quartz has planar features, reduced birefricence and in places a brownish, cloudy tint. The rock type has been termed »breccia with crystalline matrix».

3) The third rock type is also a breccia but is characterized by an aphanitic groundmass, in which the grain size is submicroscopic. Open vesicles are lacking and the numerous fragments are of granitic composition, although aphanitic or glassy, schlierenformig fragments have been met with. The rocks are dark brown owing to the oxidation of iron-bearing minerals in the groundmass. This type has been named »breccia with aphanitic matrix"».
4) The fourth group consists of breccia, which show neither oxidation of iron minerals (biotite) nor vesicles but contain fragments with lamellar quartz and feldspars as well as kinked biotite in a finegrained groundmass. The lack of recrystalline groundmass, glassy schlieren fragments, vesicles as well as the unoxidation of the iron minerals indicate that this rock type is more weakly metamorphic than breccias 2 and 3 . The type has been called »breccia».

5) The fifth rock group of this study consists of the bedrocks around Sääksjärvi. The collected samples were quartz diorites and mica-gneiss ghosts in migmatite. The latter occasionally contained garnet porphyroblasts. These rock types are typical of the country rocks in the scarce outcrops around Sääksjärvi.

\section{Chemical composition}

The rocks were analyzed by a modified rapid method at the University of Turku. Si, Ti, Al, $\mathrm{Fe}, \mathrm{Ca}$ and $\mathrm{K}$ and selected trace elements were determined by $\mathrm{X}$-ray fluorescence using a direct pelletizing method. The working curves were based on 32 analyzed rock samples. Atomic absorption specroscopy was used for $\mathrm{Mg}$ and $\mathrm{Na}$ and also the abundances of $\mathrm{Al}, \mathrm{Fe}, \mathrm{Ca}, \mathrm{K}$ were determined in this way. The results are presented in Table 1 as the calculated arithmetic mean values of each rock type. The standard deviations indicate the difference of composition in each rock group. In order to depict the compositional variations of the samples the Niggli numbers were calculated and plotted in a diagram (Fig. 1).

The average composition and standard deviations of rock group 1 indicate that the andesites are very homogenous and uniform. With regard to $\mathrm{Ca}, \mathrm{K}, \mathrm{Na}$ and $\mathrm{Ti}$ this group differs considerably from the groups of breccias $(2,3$ and 4), which together form a separate compositional group characterized by the wide variations of all the elements, especially the low $\mathrm{Ca}$ and high $\mathrm{K}$ contents. 


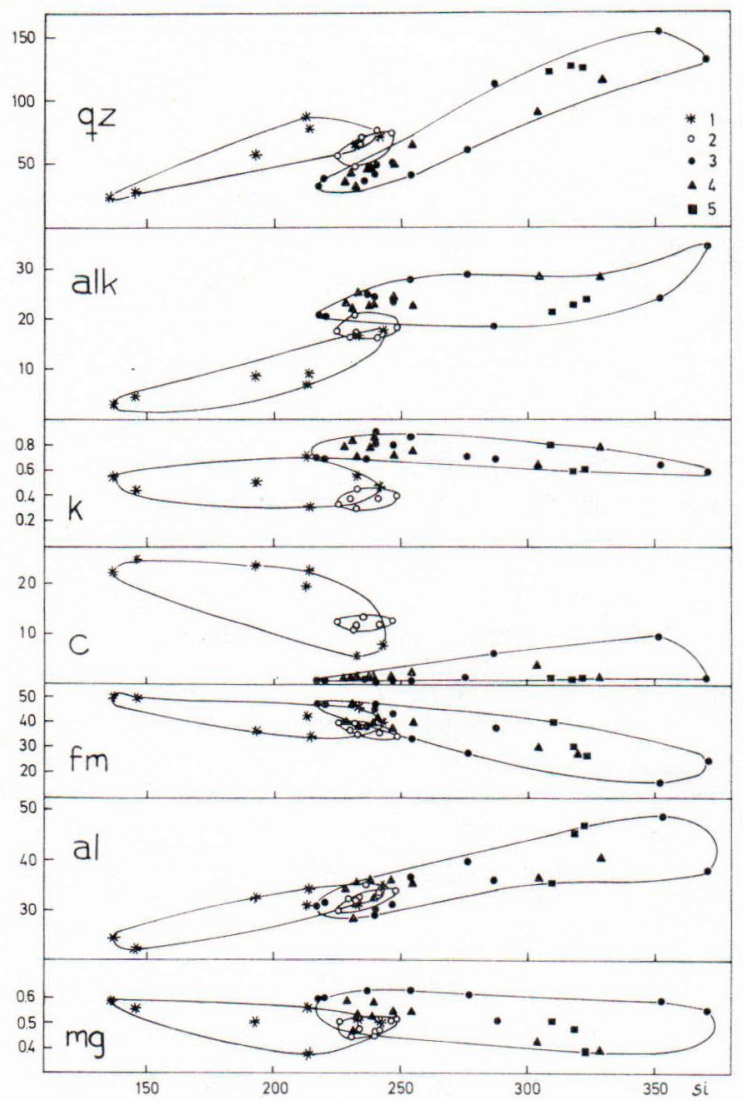

Fig. 1 A plot of the Niggli numbers of the analyzed samples of the Sääksjärvi area.

$1=$ country rocks, $2=$ andesites, $3=$ breccia with crystalline matrix, $4=$ breccia with aphanitic matrix and $5=$ breccia.

These effects are also evident in Fig. 1. On the basis of all the Niggli numbers, the country rocks were separated into group of their own. The wide variations were derived from the heterogenity of the group. The area of the first rock type, andesites, seems in Fig. 1 to be intermediate between the areas of the country rocks and the breccias. Of the selected traceelements presented in Table 1, Zr, Sr, Rb, Y and $\mathrm{Cu}$ do not show marked differences between the rock types. The abundances of $\mathrm{Zr}$ and $\mathrm{Sr}$ do tend, however, to increase slightly from breccias to andesites whereas the case is reversed with $\mathrm{Rb}$. Ni shows an obvious decrease in the series from andesites to breccias and further to country rocks. The Mn content is slightly lower in andesites and breccias than in country rocks, whereas $\mathrm{Cr}$ in breccias is lower than in andesites and especially in country rocks.

\section{Discussion}

On the basis of the forementioned chemical data of different breccias, andesite-like porphyrites and country rocks of the Sääksjärvi area, it can be concluded that the breccias and andesites both form definite groups, which in some respects differ from each other and markedly so from the country rocks. According to their $\mathrm{K}$ content the breccias in particular correspond to the potassium-rich granites. On the other hand, their $\mathrm{SiO}_{2}$ and especially their $\mathrm{CaO}$ contents are lower while their $\mathrm{Fe}_{2} \mathrm{O}_{3}$ contents are higher than e.g. in the microcline-granites or rapakivis of Southwestern Finland. In this respect the breccias are geochemically peculiar rock types. The andesite-porphyrites are rich in alkalies, but their composition does not differ much from that of the quartz-dioritic country rocks. Of the trace elements $\mathrm{Ni}$ and $\mathrm{Mn}$ show deviating figures.

The breccias have microscopic textures, which have been considered typical of shock metamorphism (e.g. Dence 1968). The matrices are either fine-grained or cryptocrystalline. Also cryptocrystalline or aphanitic vesiculated fragments have been encountered, which evidently present weakly recrystallized equivalents of former glassy fragments.

Owing to the geographical distribution of the described erratics the shallow and flat basin of Lake Sääksjärvi would seem to be their provenance. A circular form of basin with or without central uplift has been held as one of the criteria for a fossil crater.

The origin of the possible fossil crater form of Lake Sääksjärvi can be explained in two alternative ways according to explanations given to the origin of Canadian craters i.e. from meteorite impact or cryptoexplosion structures. 
The indications of both mechanisms are discussed in the following paragraphs.

\section{Meteorite impact}

The forementioned shock metamorphic textures are typical of the unquestionable meteorite craters (e.g. Meteor Crater, Arizona). In the Sääksjärvi area, however, breccias all or nearly all of the glass have not been found. This may be due to the deep erosion level of the crater, which is indicated e.g. by the flat relief of the basin and the great abundances of porphyrites and breccias with an igneous matrix. Since they are a brittle material the glassy breccias could also have been eroded in glacial drift. This possibly also explains why high pressure polymorphs of minerals have not been recorded in the samples.

The detected breccia types represent increasing shock metamorphism in the order: group 4, group 3 and group 2. In group 2, however, the residual temperature was lowered suffciently slowly to bring about the recrystallization of the groundmass.

Even if the shock metamorphic textures and the form of the Sääksjärvi basin can be explained by meteorite impact, the great differences in the composition of the breccias and country rocks are harder to explain. Since no potassium-rich and calcium-poor rocks similar to the breccias have been found during the geological bedrock mapping of the area, it would be hard to assume that a petrological anomaly such as they are, could be situated as the target rock at the impact of a meteorite. However, it has been assumed of Canadian Craters (Dence 1971), that some igneous rocks, which were formed by melting at the meteorite impact, are relatively enriched in $\mathrm{K}$ and $\mathrm{Mg}$ and depleted in $\mathrm{Si}$ and $\mathrm{Na}$; also $\mathrm{Ni}$ and $\mathrm{Fe}$ may be enriched by meteoritic contamination. Dence (1971) explains the differences between impact melt and country rock as a result of selective melting of the target rock.

The present author considers that the high content of $\mathrm{K}_{2} \mathrm{O}$ and the low $\mathrm{CaO}$ of the breccias in question cannot be derived from partial melting because the weakly shocked breccias (group 4) show compositional trends similar to the other breccias but only contain scarce melted matrix and are composed mainly of fragments. Thus their composition reflects that of primary material. The andesitic porphyrites which evidently crystallized from a melt form a compositional link between breccias and country rocks.

The interpretation that the rocks are the crystallization product of the impact melts is not satisfactory because no partially melted rocks have been found which are depleted in potassium (and enriched in calcium) in respect to the country rocks. Rock types such as these ought to exist if the potassium breccias were formed by partial melting from it.

\section{Cryptoexplosion structure}

It seems probable that in addition to fossil meteorite impact craters there are also many other crater-like, circular or semicircular structures. Of these, the "polygonal structures» described by Amstutz (1964) and Zimmermann and Amstutz (1965) which are supposed to have been produced by periodic faulting and folding as well as rigid diapiric movements should be mentioned, as should also the unquestionably volcanic explosion craters from Germany, known as »Maars». The supposition that shock metamorphic textures of minerals only exist in impact metamorphic rocks is also doubtful because any explosion violent enough can cause shock metamorphism. There is, however, another question which is still unsolved: can endogenous explosions be as violent as e.g. nuclear test explosions, which have been noted to cause shock metamorphic textures (James 1969).

Marked chemical differences between crater rocks and country rocks have been noted in Canada from East Clearwater, West Clearwater, Carswell (Currie and Shafiqullah 1968) and the Brent crater (Currie 1971). Chemical data indicate 


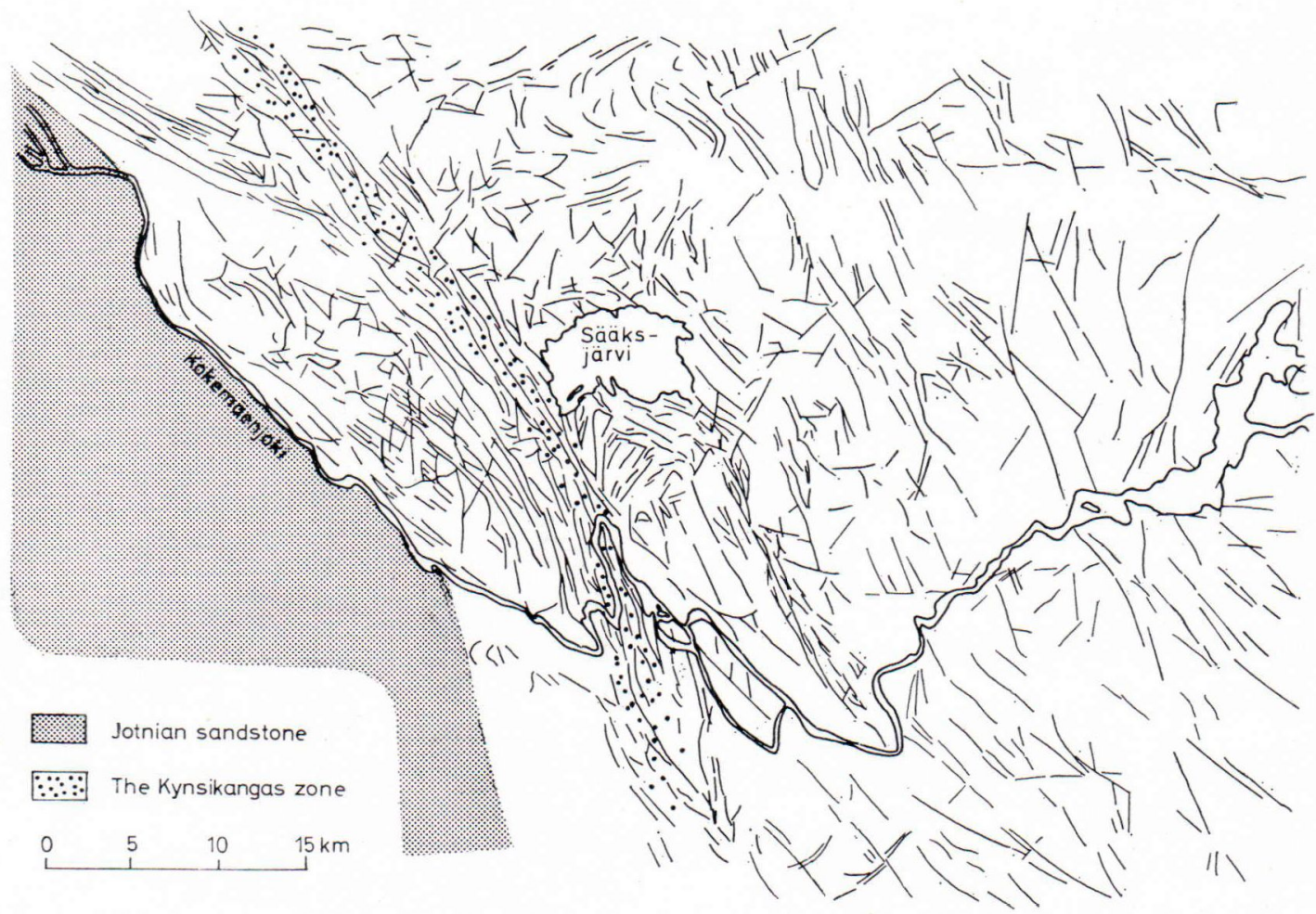

Fig. 2. Lineaments around the Lake Sääksjärvi area. Drawn on the basis of aerial photographs and topographic maps.

that differences are evidently characteristic of some types of fossil craters. Currie (1971) has proposed that both the composition and geometry of the igneous rocks of craters can be explained by endogenic volcanism if the magma has unusually high assimilative powers. Also Stanfors (1969) has suggested that the structure of Lake Mien, southern Sweden may have been produced by hot gases which penetrated the crust as a violent explosion during the initial stage of volcanism.

According to Currie (1970) most of the Canadian craters are located along the "welts» of the Canadian Precambrian shield and this structural space-time line controls the formation of endogenous explosion craters.

There are two strong fault lines close to the structure of Sääksjärvi (Fig. 2), one of which delineates the Jotnian sandstone and is located about the bed of Kokemäenjoki river. The other, the Kynsikangas zone, appears as a sheared zone almost parallel to Kokemäenjoki and closer to Säksjärvi. The deep and strong tectonic shear zones may possible cause the creation of magma at deep levels. The additional intersecting fault lines may then provide a channel for the ascending magma, fluids or gases. However, magmatic and especially volcanic activity younger than the Precambrian is lacking in the area. In this respect, there is no direct correlation with typical explosion craters. A cryptoexplosion origin, however, does explain the geochemically special features of the rocks of the Lake Sääksjärvi area.

Acknowledgements - The author thanks Mr. Timo Kopperoinen, M. A. and Mr. Simo Marttila for their cooperation in the laboratory determinations. Financial support for the research was provided by the National Research Council for Science (Valtion luonnontieteellinen toimikunta). 
Table 1.

Chemical composition of the rocks of the Sääksjärvi area

\begin{tabular}{|c|c|c|c|c|c|c|c|c|c|c|c|c|}
\hline Rock group & \multicolumn{2}{|c|}{1} & \multicolumn{2}{|c|}{ 2. A } & \multicolumn{2}{|c|}{ 2. B } & \multicolumn{2}{|c|}{3} & \multicolumn{2}{|c|}{4} & \multicolumn{2}{|c|}{5} \\
\hline $\begin{array}{c}\text { No. of ana- } \\
\text { lyses }\end{array}$ & \multicolumn{2}{|c|}{6} & \multicolumn{2}{|c|}{5} & \multicolumn{2}{|c|}{6} & \multicolumn{2}{|c|}{10} & \multicolumn{2}{|c|}{3} & \multicolumn{2}{|c|}{6} \\
\hline & a & s & a & s & a & s & a & s & a & s & a & s \\
\hline $\mathrm{SiO}_{2}$ & 64.84 & 0.64 & 66.99 & 3.10 & 64.14 & 2.33 & 66.00 & 3.71 & 68.34 & 2.20 & 62.33 & 4.27 \\
\hline $\mathrm{TiO}_{2} \ldots$. & 0.72 & 0.03 & 0.66 & 0.07 & 0.67 & 0.05 & 0.55 & 0.25 & 0.46 & 0.13 & 0.86 & 0.23 \\
\hline $\mathrm{Al}_{2} \mathrm{O}_{3} \ldots$ & 15.14 & 0.35 & 15.43 & 1.73 & 15.19 & 0.81 & 15.15 & 1.31 & 15.63 & 1.70 & 15.97 & 1.24 \\
\hline $\mathrm{Fe}_{2} \mathrm{O}_{3} \ldots$ & 6.96 & 0.61 & 5.41 & 3.14 & 6.33 & 1.04 & 5.98 & 1.54 & 5.01 & 0.90 & 8.22 & 1.37 \\
\hline $\mathrm{MgO} \ldots$ & 3.28 & 0.30 & 3.04 & 1.05 & 4.21 & 0.98 & 3.30 & 1.07 & 2.23 & 0.85 & 4.33 & 1.49 \\
\hline $\mathrm{CaO} \ldots \ldots$ & 3.31 & 0.19 & 0.59 & 0.13 & 0.44 & 0.51 & 0.39 & 0.19 & 0.31 & 0.03 & 5.06 & 2.79 \\
\hline $\mathrm{K}_{2} \mathrm{O} \ldots$ & 2.84 & 0.24 & 7.80 & 1.70 & 7.05 & 1.41 & 7.38 & 0.60 & 5.24 & 0.83 & 2.36 & 1.20 \\
\hline $\mathrm{Na}_{2} \mathrm{O} \quad \ldots$ & 3.20 & 0.60 & 1.48 & 0.47 & 1.68 & 0.33 & 1.66 & 0.62 & 1.65 & 0.62 & 1.65 & 0.78 \\
\hline
\end{tabular}

Trace elements in ppm

\begin{tabular}{l|r|r|r|r|r|r} 
& \multicolumn{5}{|c|}{ Trace elements in ppm } \\
$\mathrm{ZrO}_{2} \ldots$ & 345 & 290 & 300 & 240 & 190 & 210 \\
$\mathrm{SrO}_{2}$ & 230 & 120 & 130 & 110 & 70 & 120 \\
$\mathrm{Rb}_{2} \mathrm{O} \ldots$ & 110 & 140 & 140 & 160 & 150 & 80 \\
$\mathrm{Y} \ldots \ldots$ & 80 & 70 & 80 & 90 & 90 & 80 \\
$\mathrm{Cu} \ldots \ldots$ & 100 & 90 & 100 & 100 & 90 & 160 \\
$\mathrm{Zn} \ldots \ldots$ & 80 & 190 & 30 & 30 & 180 & 190 \\
$\mathrm{Ni} \ldots \ldots$ & 500 & 360 & 330 & 340 & 770 & 1380 \\
$\mathrm{Mn} \ldots \ldots$ & 480 & 250 & 360 & 410 & 830 & 1600
\end{tabular}

$\mathrm{a}=$ arithmetic mean

$\mathrm{s}=$ standard deviation

1. andesites

2. A breccia with crystalline matrix, light brown
2. B breccia with crystalline matrix, greenish

3. breccia with aphanitic matrix

4. breccia

5. country rocks

\section{REFERENCES}

Amsturz, G. C. (1964) Tectonic and petrographic observations on polygonal structures in Missouri. Ann. New York Academy Sci. 123, 876-894.

Currie, K. L. (1970) New Canadian cryptoexplosion crater at Lake St Martin, Manitoba. Nature, 226, $839-841$.

Currie, K. L. (1971) Origin of igneous rocks associated with shock metamorphism as suggested by geochemical investigations of Canadian craters. Journ. Geoph. Res. 76, 5575-5585.

Currie, K. L. and Shafiqullah M. (1968) The geochemistry of some large Canadian craters, Nature $218,457$.

DENCE, M. R. (1968) Shock zoning at Canadian craters: petrography and structural implications. In »Shock metamorphism of natural materials» ed. B. M. French and N. M. Short, Mono, Baltimore, 1969.

Dence, M. R. (1971) Impact melts. Journ. Geoph. Res. $76,5552-5565$.

JAmes, O. B. (1969) Shock and thermal metamorphism of basalt by nuclear explosion, Nevada test site. Science $166,1615-1620$.
LeHTINEN, M. (1970) New evidence for an impact origin of Lake Lappajärvi, western Finland. Bull. Geol. Soc. Finland 42, 89-93.

Papunen, Heik i (1969) Possible impact metamorphic textures in the erratics of the Lake Sääksjärvi area in southwestern Finland. Bull. Geol. Soc. Finland, 41, $151-155$.

Saksela, M. (1949) Das pyroklastische Gestein von Lappajärvi und seine Verbreitung als Geschiebe. C. R. Soc. géol. Finlande, 22, 19-30.

Stanfors, Roy (1969) Lake Mien - an astrobleme or a volcano tectonic structure. Geol. Fören. i Stockholm Förh. 91, 73-86.

Svensson, N. B. (1968) Lake Lappajärvi central Finland; possible meteorite impact structure. Nature 217, 438.

Zimmermann R. A. and Amstutz G. C. (1965) The polygonal structure at Decaturville, Missouri: new tectonic observations. N. Jb. Miner Mh. 9-11, $288-307$.

Manuscript received, March 15, 1972. 